\title{
The Impact of Ageing Population on Economic Growth in South Asia
}

\author{
D.K.Y. Abeywardhana ${ }^{1}$ \\ ${ }^{1}$ Department of Accountancy, University of Kelaniya, Sri Lanka \\ Correspondence: D.K.Y. Abeywardhana. Tel: 947-1460-1643. E-mail: dilyapa@kln.ac.lk
}

$\begin{array}{lr}\text { Received: May 8, } 2019 & \text { Accepted: June 17, } 2019 \quad \text { Online Published: June 30, } 2019 \\ \text { doi:10.5539/ass.v15n7p70 } & \text { URL: https://doi.org/10.5539/ass.v15n7p70 }\end{array}$

\begin{abstract}
The share of working age population has declined all over the world. It is forecasted that this will continue for the coming years in all countries in South Asia. Low growth in working age population in South Asia will be effecting negatively for the economic growth. This paper studies whether the South Asia 2050 employment targets would be sufficient to compensate for the downward impact of demographic burden and whether the impact of demography on economic growth differs between South Asian countries. The results show that degreasing working age population is the main challenge the South Asian region faces. Further it shows that growth in GDP mainly depend on the demographic change. Population who contributed the economic development become maturing and dependents of their children. The consumption of the ageing population is very high as of higher spending on healthcare facilities. This effect badly on the economic growth in the region and cause lots of challenges to the nations.
\end{abstract}

Keywords: demographic burden, economic growth, ageing population, South Asia

\section{Introduction}

All over the world, the number of people age over 60 and above is estimated to grow gradually over the coming years. In Asia this has increased from 207 million in year 2000 to 857 million in year 2050. Improvement in science and technology in the health sector improved the health condition of the people and as a result the death rates in the world reduced. At the same time in the twentieth century countries in the world controlled the birth rate and became succeeded in controlling population growth. This has created the biggest social challenge to the whole world (United Nations 2017). High proportion of dependents (children and elders) in the population reduces the working age population and increases the expenses on caring young and elderly which cause to decrease the economic growth of the country. Economic growth and working age population shows positive relationship (Headly \& Hodge, 2009). Further Misra (2017) confirmed the same that demographic dividends has a positive impact on economic growth. Economic growth of a country depends on number, efficiency of working age population and technological innovation. Working more people increase the savings of the country where there would be an increase in investments. On the other hand working more people means less number of dependents are there in the economy. Moreover, working more people improve the infrastructure for education and that will ultimately lead to improve the quality of the labor force of the world in the future.

Declining fertility and changes in the age structure of the population decrease the working age population. As working age population decrease demographic dividend become demographic burden to the country. Higher the population aging lower the economic growth of the country as the decline in working age population reduces the labor force, wages and productivity, savings and industrial investments.

Change in age structure of the population is experiencing every single country in the world. Growth rate of the working age population is much slower than the growth rate of total population. This situation is severe for the Asian region. Table 1 shows the population of the major areas in the world from 2015 to 2100 . Out of 7.3 billion of world population 4.4 billion lives in Asia which accounts for $60 \%$. China and India being the two largest countries in the world represent $19 \%$ and $18 \%$ of the world population respectively.

According to the most recent data in $2015,50.4 \%$ is male and $49.6 \%$ is female and $12 \%$ of the world population is 60 or over 60 years old. Only $62 \%$ are aged $15-59$ and would be able to work and more than a quarter (28\%) of the population are under 15 years old and over 60 years old (figure 1). This has been studied in several recent studies (Prskawetz, 2007; Bloom et al., 2003) and concluded that age structure matters for the economic growth. Change in the age structure is the major concern in research on ageing population and the objective of this study 
is to analyze the impact of ageing population on the economic growth in the South Asia.

Table 1. Population of the World and Major Areas, 2015, 2030, 2050 and 2100, according to the medium-variant projection

\begin{tabular}{ccccc}
\hline Major Area & \multicolumn{4}{c}{ Population (Millions) } \\
\cline { 2 - 5 } & 2015 & 2030 & 2050 & 2100 \\
\hline World & 7349 & 8501 & 9725 & 11213 \\
Africa & 1186 & 1679 & 2478 & 4387 \\
Asia & 4393 & 4923 & 5267 & 4889 \\
Europe & 738 & 734 & 707 & 646 \\
Latin American and the Caribbean & 634 & 721 & 784 & 721 \\
Northern America & 358 & 396 & 433 & 500 \\
Oceania & 39 & 47 & 57 & 71 \\
\hline
\end{tabular}

Source: United Nations, Department of Economic and Social Affairs, Population Division (2015).

World Population Prospects: The 2015 Revision. New York: United Nations.

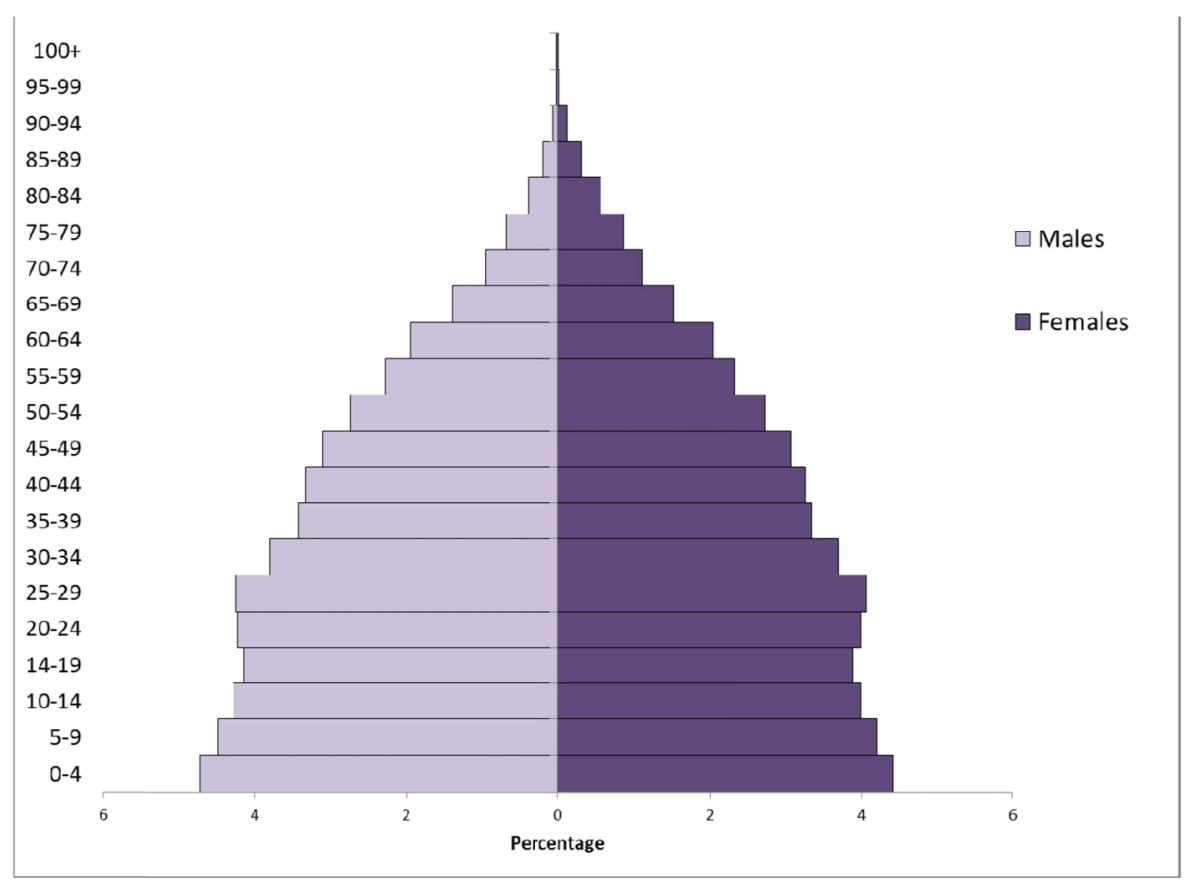

Figure 1. Distribution of world population by age and sex

Source: World Population Prospects. The 2015 Review, United Nations

Van der Gaag and De Beer (2015) studied the demographic dividends for the European Union countries for the period of 2000-2010, and forecasted for 2010-2020. Further in this study it was observed that population ageing have led to decrease in working age population and increase in elderly population. Consequences of this change in ageing structure of population would lead to increase in dependency ratio (Swiaczny et al., 2008; Tivig et al., 2008). According to Lee et al., (2011) to sustain economic growth over the next decades, countries should promote savings, industrial investment, investment in human capital, well-functioning financial and labor markets and macroeconomic stability. The question remains will South Asian countries be able to return to its growth route with the continuous reduction of working age population? This paper focus on the recent and expected development of labor supply on the economic growth in the South Asia, the world's fastest growing economy in the period 2000-2050. Main purpose of this paper is to discuss the impact of population ageing on the economic growth of the South Asian region.

The rest of this paper is organized as follows. Section one discuss the demography and the economic growth, Section two will focus on working age population and economic growth of countries of the study and the theoretical background to the study and in the Section three discuss the demographic dividend and demographic 
burden for the South Asian countries and finally the Section four will provide the conclusions and recommendations.

\section{Working Age Population and Economic Growth}

Population ageing in South Asia is due to lower fertility and longer life expectancy as per the other parts of the world. According to Lee et al., (2011) Asian economies faces significant differences in the timing and speed of the fertility and mortality declines. Rapid decline in the birth rates and the lower percentage of children in the population increase the working age population which give a direct and favorable impact on the economic growth of the region. But the South Asian economies face a decline in the working age population and increase of the older population have massive impact to the economic growth of the region. Working age population in Asian economies has already started to decline and older population has increased rapidly (Lee et al., 2011). Population growth has been identified as an important criteria in determining economic growth (Peterson, 2017). Further Park and Shin (2012) found that the change in demographic pattern have a significant influence on the economic growth of the country. Economic growth can be measured as the annual percentage change in Gross Domestic Product (GDP) per capita. Following Denton and Spencer (1997) GDP can be decomposed as follows.

$$
\text { GDP }=\text { Pop } x \text { WAP/Pop } \mathrm{x} \text { workers/WAP } \mathrm{x} \text { hours/workers } \mathrm{x} \text { GDP/hours }
$$

Where,

$G D P=$ Gross Domestic Product,

Pop $=$ total Population,

$W A P=$ Working Age Population defined as population aged 20-64,

workers $=$ total number of persons in the work force and

hours $=$ total number of hours worked.

Based on World Bank data this study calculated the above equation. Table 02 shows the GDP for the year 2017 and other measures which affect to GDP.

Table 2. The GDP for the year 2017 and other measures which affect to GDP

\begin{tabular}{cccccccc}
\hline & \multicolumn{2}{c}{ GDP } & \multicolumn{2}{c}{ Population } & & Labour Market & Productivity \\
\cline { 2 - 8 } Country & GDP (US \$) & $\begin{array}{c}\text { GDP (Per } \\
\text { Capita) }\end{array}$ & Population & WAP/Pop & Workers/WAP & Hours/Workers & GDP/Hours \\
\hline AFG & 20815300220.04 & 40016.43 & 35530081 & 0.4232 & 0.3266 & 679.49 & 2.80 \\
BGD & 249723887765.42 & 119986.54 & 164669751 & 0.5669 & 0.3971 & 825.98 & 4.53 \\
BTN & 2511852941.17 & 211495.64 & 807610 & 0.5938 & 0.2844 & 591.55 & 10.72 \\
IND & 2597491162897.67 & 125089.13 & 1339180127 & 0.5691 & 0.2096 & 436.11 & 11.44 \\
LKA & 87174682200.43 & 619728.89 & 21444000 & 0.5824 & 0.5715 & 1188.82 & 8.40 \\
MDV & 4597083303.50 & 161900.39 & 436330 & 0.6576 & 0.7402 & 1539.69 & 13.57 \\
NPL & 24472013233.84 & 88695.91 & 29304998 & 0.5198 & 0.1987 & 413.33 & 3.47 \\
PAK & 304951818494.06 & 162233.61 & 197015955 & 0.5095 & 0.3888 & 808.89 & 5.38 \\
\hline
\end{tabular}

Afghanistan (AFG), Bangladesh (BGD), Bhutan (BTN), India (IND), Sri Lanka (LKA), Maldives (MDV), Nepal (NPL) and Pakistan (PAK)

GDP: Gross Domestic Product in US\$ and per capital value

Population: Population at $1^{\text {st }}$ of January 2017

WAP/Pop: the population age 20-64 divided by total population at $01^{\text {st }}$ January 2017

Hours/Workers: Total number of hours worked over the year divided by the average number of people in employment

GDP/Hours: GDP/Hours Worked

Table 2 shows that average employment rate is less than 50\% in Afghanistan and just above average in Pakistan and Nepal. These countries productivity is very low as the employment rate is low. Compared to other countries Sri Lanka shows the highest per capita GDP in 2017 in the south Asia. Lowest number of hours worked in Nepal and surprisingly second lowest is the India the country with highest population and GDP in South Asia. This is 
because in India employment rate is just 21\%. Maldives shows the highest employment rate in South Asia and they have the highest number of working hours. Productivity of the workforce is also the highest in Maldives.

An analysis of different components of labour inputs to GDP for different periods as shown in Figure 2, 3, 4 and 5 reveals a negative contribution from all component of labour inputs to GDP in South Asia. Rapid increase in population and lower level of employment rate has negatively affected to the GDP. Increase in unemployment means decrease in number of working hours and this has negatively exaggerated GDP growth in all the countries during the period 1960 - 2017, 2000 - 2017, 2010 - 2017 and 2013 - 2017. This emphasize that population growth has adverse long run effects on the countries with lower level of development. Decreasing labour hours has negatively affected the GDP growth in all the countries in South Asia. Lower GDP growth is evident the lower employment and lower working hours in South Asia.

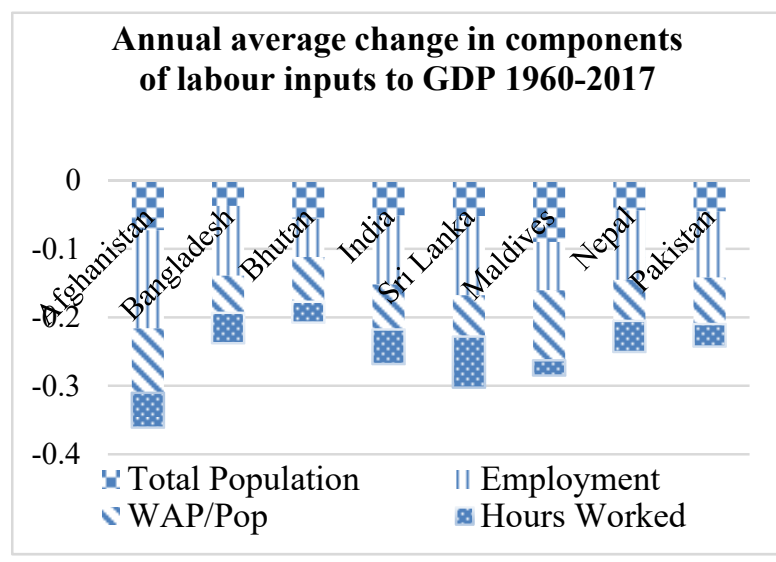

Figure 2. Annual average change in components of labour inputs to GDP 1960-2017

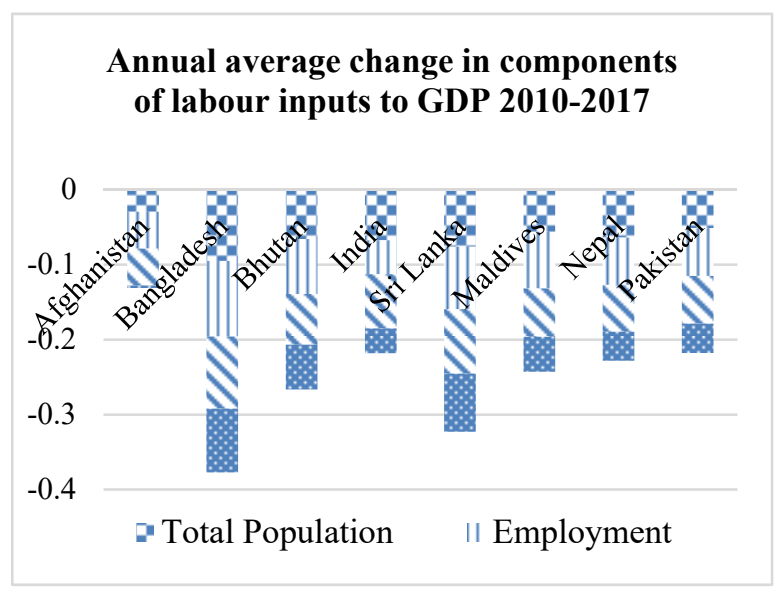

Figure 4. Annual average change in components of components of labour inputs to GDP 2010-2017

\section{Annual average change in components of labour inputs to GDP 2000-2017}

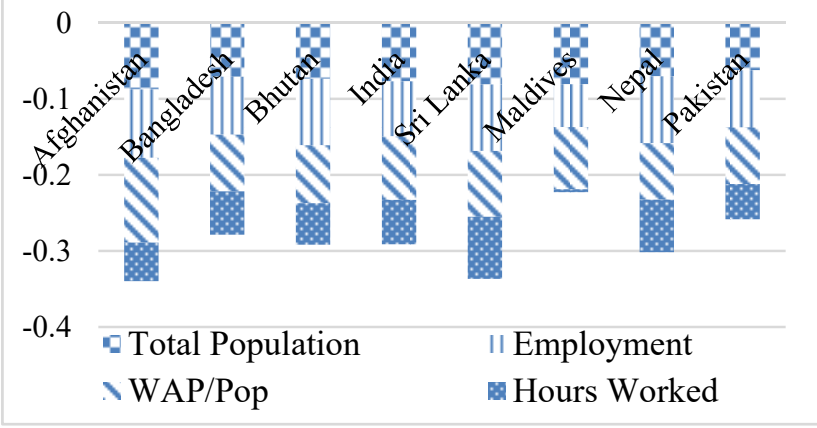

Figure 3. Annual average change in components of labour inputs to GDP 2000-2017

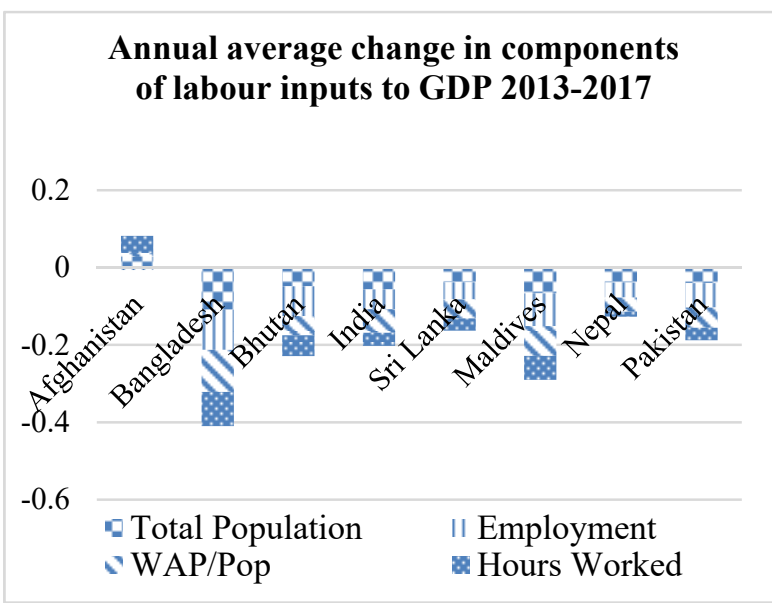

Figure 5. Annual average change in labour inputs to GDP 2013-2017

It is evident that for the last 5 decades in South Asia population to GDP is negative. This is because continuous decrease in working age population, decrease in hours worked and increase in unemployment in South Asia. Period wise analysis shows that annual average change from 2013-2017 in Afghanistan only indicates a positive move whereas none of the other countries in South Asia demonstrates a positive move.

According to Lee et al. (2012) population aging in Asia is due to lower fertility and longer life expectancy. Further it is indicated in UN (2009) report in South Asia populations are relatively young, percentage of children is declining, birth rate is rapidly declining and the share of working age population is also declining. In South Asia the one reason apart from the above, for lower level of working age population would be migration. According to the Figure 6 demographic dividend experience almost all the countries except Sri Lanka and 
Maldives in South Asia as working age population (Figure 7) grow relatively to their dependents. In Sri Lanka and Maldives anticipated a negative working age population (UN, 2015) and in Sri Lanka, where relatively large proportions of the population are elderly compared to other countries in South Asia (Appendix A).

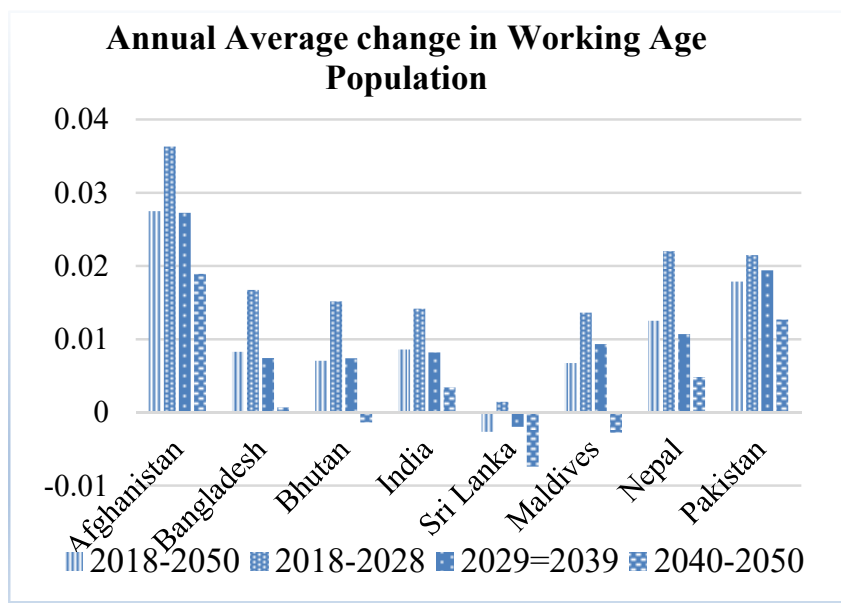

Figure 6. Annual average change in Total Population

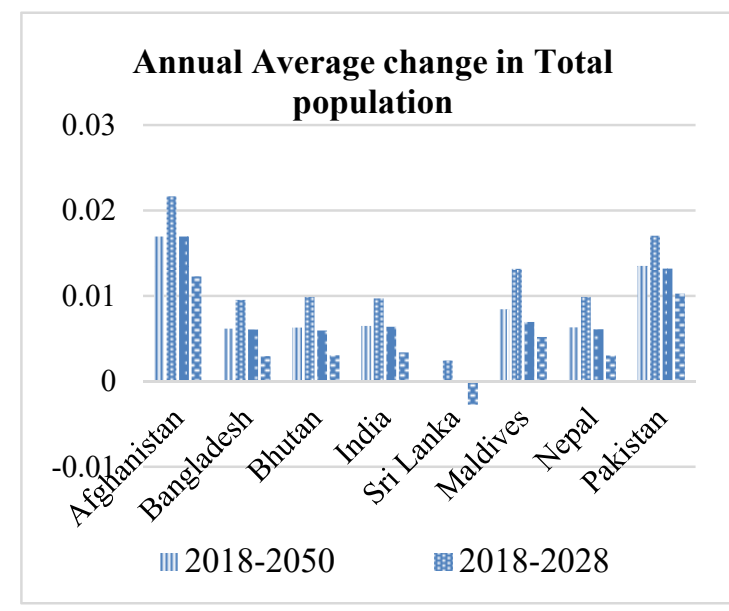

Figure 7. Annual average change in Working Age Population

It is estimated that average $37 \%$ of the total population in South Asia are under 19 years old by year 2025 and average $6.5 \%$ of them are over 65 years. As shown in Appendix A average $43 \%$ is dependents in the population. This unparalleled pace of population aging must manage to ensure the economic development of the region. In some countries like Sri Lanka old age population is very high compared to other countries and in Afghanistan population aged under 19 years is more than $50 \%$ of the total population. Over the time great increase in old age population and under aged population will lead to lower GDP growth in the region. The question is how these countries meet their employment targets in the future.

Further, as per the estimated figures demographic burden continue until 2050 and working age population of some countries in South Asia decrease in the coming decades. As a result economic growth in the region should establish a mechanism to increase employment and to increase the productivity.

\section{Discussion and Conclusion}

Objective of this paper is to discuss the past and recent development in population aging on economic growth in South Asia. It is evident that the growth in the GDP mainly depends on the demographic change and in the future and decrease in working age population is the main challenge the South Asia faces. Population who contributed to the economy is maturing and they become dependents of their children. This is an issue handled by the governments. How best can they be meet the requirements of this elderly generation? How these government policies would be affecting to the younger generation and to the economic growth of the country? Improvement in health facilities and reduction in mortality cause this population ageing. This unparalleled pace of population ageing alarm the policy makers to invest in human capital and to generate savings and investment. The pressure to the economy is very high as the older population consumption is very high because of higher spending on healthcare and in most of the countries this expenses are borne by the government. This indicate that in South Asia economic growth will be significantly affected by the population ageing. Magnitude of population ageing would vary from country to country thus this would pose lots of challenges to these nations.

Policy makers should alarm and understand that the link between demographic dividends and GDP growth can be policy dependent. This proposes strong empirical justification for establishing national policy to set and achieve target economic growth. So it is important for these countries to have employment generation policies, increase investment in old age support systems, encourage self-dependency to alleviate the burden of rapid population ageing on the economy, to reduce cost of older age dependents and thereby increase the working age population and reap the economic growth.

\section{References}

Bloom, D. E., Canning, D., \& Sevilla, J. (2003). The Demographic Dividend, a New Perspective on the Economic Consequences of Population Change. Population Matters. Monograph MR 1274. Santa Monica, CA: RAND. https://doi.org/10.7249/MR1274 
Denton, F., \& Spencer, B. G. (1997). Population, Labour Force and Long-term Economic Growth. IESOP Research Paper No. 25.

Headey, D. D., \& Hodge, A. (2009). The Effect of Population Growth on Economic Growth: A Metaregression Analysis of the Macroeconomic Literature. Population and Development Review, 35, 221-248. https://doi.org/10.1111/j.1728-4457.2009.00274.x

Lee, S. H., \& Mason, A. (2011). The Economic Lifecycle and Support System in Asia. ADB Economic Working Paper.

Lee, S. H., Mason, A., \& Park, D. (2012). Overview: why does population aging matter so much for Asia? Population aging, economic growth, and economic security in Asia. ADB Publication. https://doi.org/10.4337/9781781953600.00007

Misra, R. (2017). Impact of Demographic Dividend on Economic Growth: A Study of BRICS and the EU. International Studies, 52, 1-4. https://doi.org/10.1177/0020881717714685

Park, D., \& Shin, K. (2012). Impact of population aging on Asia's future growth. Edward Elgar Publishing Limited. https://doi.org/10.4337/9781781953600.00009

Prskawetz, A., Fent, T., Barthel, W., Crespo-Cuaresma, J., Lindh, T., Malmberg, B., \& Halvarsson, M. (2007). The Relationship between Demographic Change and Economic Growth in the EU. Report for Tender VT/2005/035.

Swiaczny, F., Graze, P., \& Schlömer, C. (2008). Spatial impacts of demographic change in Germany. Urban population processes reconsidered. In Zeitschrift für Bevölkerungswissenschaft, 33(2), 181-205. https://doi.org/10.1007/s12523-009-0010-9

Tivig, T., Frosch, K., \& Kühntopf, S. (2008). Mapping regional demographic change and regional demographic location risk in Europe. Rostock: Rostock Center for the Study of Demographic Change.

United Nations. (2015). World population prospects: The 2015 Revision. Population Division of the Department of Economic and Social Aff airs of the United Nations Secretariat.

Van der Gaag, N., \& De Beer, J. (2015). From demographic dividend to demographic burden: the impact of population ageing on economic growth in Europe. Journal of Economic and Social Geography, 106(1), 94-109. https://doi.org/10.1111/tesg.12104

Wesley, E., \& Peterson, F. (2017). The Role of Population in Economic Growth (pp. 1-15). SAGE Open.

\section{Appendix A}

Share of population aged 0-19(\%)

\begin{tabular}{ccccccc}
\hline & 1950 & 1975 & 2000 & 2010 & 2025 & 2050 \\
\hline Afghanistan & 52.9 & 54.8 & 57.6 & 56.9 & 53.6 & 43.2 \\
Pakistan & 43.7 & 52.1 & 52.1 & 47.4 & 41.2 & 30.8 \\
Bangladesh & 49.1 & 55.3 & 48.4 & 41.0 & 32.5 & 24.4 \\
Bhutan & 54.1 & 50.8 & 51.7 & 40.8 & 32.7 & 24.6 \\
India & 47.7 & 50.6 & 45.2 & 40.8 & 33.2 & 24.5 \\
Maldives & 42.1 & 52.4 & 52.7 & 39.3 & 31.1 & 23.3 \\
Nepal & 51.4 & 52.4 & 51.6 & 47.0 & 38.1 & 28.7 \\
Sri Lanka & 47.4 & 48.3 & 36.4 & 31.9 & 29.1 & 23.5 \\
\hline Share of population aged & 65 and older (\%) & & & & \\
\hline Afghanistan & 2.6 & 2.3 & 2.2 & 2.2 & 2.4 & 3.6 \\
Pakistan & 7.0 & 5.0 & 3.7 & 4.1 & 5.1 & 10.0 \\
Bangladesh & 3.1 & 3.1 & 3.4 & 4.0 & 6.1 & 14.9 \\
Bhutan & 2.5 & 2.7 & 4.4 & 4.9 & 6.5 & 15.0 \\
India & 3.1 & 3.4 & 4.3 & 4.9 & 7.3 & 13.7 \\
Maldives & 5.1 & 4.4 & 3.4 & 4.4 & 5.5 & 16.8 \\
Nepal & 1.9 & 3.0 & 3.5 & 4.1 & 5.2 & 10.6 \\
Sri Lanka & 10.0 & 4.0 & 6.4 & 7.9 & & 21.4 \\
\hline
\end{tabular}


Share of population aged 20-64 (\%)

\begin{tabular}{cllllll}
\hline Afghanistan & 44.6 & 42.8 & 40.2 & 40.9 & 44.0 & 53.2 \\
Pakistan & 49.3 & 42.9 & 44.2 & 48.5 & 53.6 & 59.2 \\
Bangladesh & 47.9 & 41.6 & 48.2 & 55.0 & 61.4 & 60.6 \\
Bhutan & 43.3 & 46.6 & 43.9 & 54.3 & 60.7 & 60.3 \\
India & 49.2 & 46.0 & 50.5 & 54.3 & 59.4 & 61.8 \\
Maldives & 52.8 & 43.2 & 43.9 & 56.3 & 63.4 & 59.9 \\
Nepal & 46.7 & 44.6 & 44.9 & 48.9 & 56.7 & 60.7 \\
Sri Lanka & 42.7 & 47.7 & 57.2 & 60.3 & 57.0 & 55.1 \\
\hline
\end{tabular}

\section{Copyrights}

Copyright for this article is retained by the author(s), with first publication rights granted to the journal.

This is an open-access article distributed under the terms and conditions of the Creative Commons Attribution license (http://creativecommons.org/licenses/by/4.0/). 